\title{
Role of eicosanoids, nitric oxide, and afferent neurons in antacid induced protection in the rat stomach
}

\author{
N Lambrecht, M Trautmann, R Korolkiewicz, M Liszkay, B M Peskar
}

\begin{abstract}
The mechanism underlying the mucosal protective effect of antacids is still unclear. This study shows that in rats the aluminum containing antacid, hydrotalcit, induces dose dependent protection against gastric mucosal damage caused by ethanol or indomethacin which is considerably enhanced by acidification. Hydrotalcit did not increase gastric mucosal formation or the intraluminal release of prostaglandins, and did not prevent the increase in mucosal leukotriene $\mathbf{C}_{4}$ formation in response to ethanol. Pretreatment with indomethacin did not attenuate the protective effect of unmodified or acidified hydrotalcit. Furthermore, hydrotalcit significantly reduced the gastric damage caused by indomethacin even when it was administered up to 2 hours after the ulcerogen. In indomethacin treated rats, simultaneous administration of hydrotalcit did not affect the concentrations of indomethacin in serum or inflammatory exudates nor did it attenuate the inhibition of prostaglandin release into the exudates. In hydrotalcit treated rats there was no attenuation of the increase in sulphidopeptide leukotriene release or decrease in leukocyte influx into inflammatory exudates elicited by indomethacin administration. Functional ablation of afferent neurons and inhibition of endogenous nitric oxide partially antagonised the protective effect of unmodified, but not of acidified, hydrotalcit. It is concluded that (i) the protective effect of unmodified and acidified hydrotalcit is independent of the eicosanoid system; (ii) protection against indomethacin induced gastric lesions does not require treatment before dosing of the ulcerogen and does not interfere with absorption and antiinflammatory actions of indomethacin; (iii) endogenous nitric oxide and afferent neurons contribute partly to the effect of unmodified, but not of acidified, hydrotalcit suggesting that different mechanisms mediate their mucosal protective activity.
\end{abstract}

(Gut 1993; 34: 329-337)

Experimental Clinical Medicine, Ruhr-

University of Bochum,

Bochum and Bayer AG, Leverkusen, Germany N Lambrecht

M Trautmann

R Korolkiewicz

M Liszkay

B M Peskar

Correspondence to:

Dr B M Peskar, Department of Experimental Clinical

Medicine, Ruhr-University of Medicine, Ruhr-University of D-4630 Bochum, Germany.

Accepted for publication

21 July 1992

Aluminum containing antacids have been shown to protect the gastric mucosa against a variety of noxious agents. This protective effect is not mediated by their acid buffering capacity, however, since it occurs in both acid related ${ }^{1-5}$ and acid independent mucosal injury. ${ }^{1-35-9}$ Furthermore, recent investigations have shown that acidification of aluminum containing antacids, which results in complete loss of acid neutralising capacity, does not diminish, and even noticeably enhances, their protective activity. ${ }^{3.59}$ The mechanism underlying antacid induced gastroprotection has not been fully explained. It has been suggested that stimulation of endogenous prostaglandin formation in the stomach mediates, at least partly, the protective effect. ${ }^{110}$ We have investigated whether treatment with the aluminum containing antacid, hydrotalcit $\left(\mathrm{Mg}_{6} \mathrm{Al}_{2}(\mathrm{OH})_{16} \quad \mathrm{CO}_{3} \times 4 \quad \mathrm{H}_{2} \mathrm{O}\right)$, affects gastric mucosal generation of eicosanoids ex vivo and in vivo and whether a functioning prostaglandin system is a prerequisite for the mucosal protective effect in rats. In addition, we have investigated whether the hydrotalcit induced protection against lesions caused by indomethacin is related to reduced absorption of the ulcerogen.

Recently, nitric oxide (NO) has been described as a potent endothelium derived vasodilating mediator (for review see ${ }^{\prime \prime}$ ). Endogenous NO contributes to the maintenance of gastric mucosal integrity ${ }^{12}$ and is involved in the modulation of the gastric mucosal microcirculation..$^{13}$ Furthermore, NO is a major mediator of the prevention of gastric mucosal damage elicited by the stimulation of afferent neurons in response to capsaicin $^{1+}$ and of the gastroprotective effect of the antiulcer drug, carbenoxolone. ${ }^{15}$ We have, therefore, investigated whether the inhibitors of NO biosynthesis, $\mathrm{N}^{\mathrm{G}}$-nitro- $\mathrm{L}$-arginine (L-NNA) and its methyl-ester (L-NAME)" modify the mucosal protective effect of unmodified and acidified hydrotalcit. In addition, studies were performed to investigate whether protection elicited by hydrotalcit involves stimulation of capsaicin sensitive afferent neurons.

\section{Methods}

MATERIALS

Hydrotalcit was obtained from Bayer AG (Leverkusen, Germany). Indomethacin, L-NNA, L-NAME, prostaglandins, leukotriene $\mathrm{C}_{4}\left(\mathrm{LTC}_{4}\right)$, and all other chemicals were purchased from Sigma chemicals Co (St Louis, MO, USA). [ $\left.{ }^{3} \mathrm{H}\right]-\mathrm{PGE}_{2}, \quad\left[{ }^{3} \mathrm{H}\right]-6-$ keto-PGF ${ }_{1 \omega}$, $\left[{ }^{3} \mathrm{H}\right]-\mathrm{LTC}_{4}$, and $\left[{ }^{[+} \mathrm{C}\right]$-indomethacin were from New England Nuclear Co (Dreieich, Germany).

Two hydrotalcit preparations were used in the 
over 24 hours. Both hydrotalcit suspensions were prepared in such a way that the desired dose was administered in $5 \mathrm{ml} / \mathrm{kg}$.

\section{EXPERIMENTAL PROTOCOL}

Male Wistar rats (weighing 180-220 g) were used in all experiments. They were housed in a controlled environment $\left(22 \pm 1^{\circ} \mathrm{C}\right)$ with a 12 hour light/dark cycle. Rats were deprived of food for 24 hours but had free access to water before the start of the experiments.

\section{GASTRIC MUCOSAL PROTECTION STUDIES}

\section{Ethanol induced gastric lesions}

Groups of six rats were treated orally with graded doses of unmodified $(80-750 \mathrm{mg} / \mathrm{kg}$ ) or acidified $(40-200 \mathrm{mg} / \mathrm{kg})$ hydrotalcit 60 minutes before intragastric instillation of $1.5 \mathrm{ml}$ of absolute ethanol. Because of the volume of the compound, $750 \mathrm{mg} / \mathrm{kg}$ unmodified hydrotalcit is the maximum dose that can be introduced into the stomach. Five minutes after the ethanol instillation, the stomach was removed under ether anaesthesia and mucosal damage was assessed in a blinded manner by calculation of a lesion index based on a 0-3 scoring system as described elsewhere. ${ }^{17}$ Previous studies have shown that the mucosal damage is maximal within 5 minutes of ethanol exposure and no worsening occurs after that. ${ }^{17}$ Furthermore, pilot experiments have ascertained that identical protective effects of unmodified and acidified hydrotalcit can be shown when a 5 minute or 60 minute observation period after ethanol challenged is used. Control rats were treated with the same volume of the corresponding vehicle $(5 \mathrm{ml} / \mathrm{kg}$ of $0.25 \% \mathrm{MC}$ or $0 \cdot 25 \% \mathrm{MC}$ acidified to $\mathrm{pH} 2 \cdot 5)$.

To investigate the time course of protection, groups of four to 12 rats were treated orally with unmodified $(750 \mathrm{mg} / \mathrm{kg})$ or acidified $(200 \mathrm{mg} / \mathrm{kg}$ or $90 \mathrm{mg} / \mathrm{kg}$ ) hydrotalcit. Initial protection by 90 $\mathrm{mg} / \mathrm{kg}$ of acidified hydrotalcit is equal to the protection elicited by $750 \mathrm{mg} / \mathrm{kg}$ of unmodified hydrotalcit. Rats were challenged with intragastric absolute ethanol $(1 \cdot 5 \mathrm{ml}) 1,2,3,5,8,11$, or 16 hours after hydrotalcit administration and gastric mucosal damage was assessed 5 minutes later.

\section{Pretreatment with indomethacin}

Groups of rats were treated with subcutaneous indomethacin $(20 \mathrm{mg} / \mathrm{kg}) 60$ minutes before oral administration of unmodified $(750 \mathrm{mg} / \mathrm{kg})$ or acidified $(200 \mathrm{mg} / \mathrm{kg})$ hydrotalcit. One hour later, ethanol was instilled intragastrically and rats were killed 5 minutes later. Mucosal damage was assessed and gastric mucosal fragments were incubated for determination of prostaglandin formation.

Pretreatment with inhibitors of NO biosynthesis Groups of rats were injected intravenously with L-NNA $(40 \mathrm{mg} / \mathrm{kg}$, dissolved in $2.5 \mathrm{ml} / \mathrm{kg}$ of saline) 10 minutes before oral administration of graded doses of unmodified $(250-750 \mathrm{mg} / \mathrm{kg})$ or acidified (50-200 mg/kg) hydrotalcit. Thirty minutes after administration of the protective agent, ethanol $(1.5 \mathrm{ml})$ was introduced intragastrically and mucosal damage was assessed 5 minutes later. Controls were injected with saline $(2.5 \mathrm{ml} / \mathrm{kg})$ instead of L-NNA and were treated orally with $0.25 \% \mathrm{MC}$ or $0.25 \% \mathrm{MC}$ acidified to $\mathrm{pH} 2 \cdot 5$. Since $40 \mathrm{mg} / \mathrm{kg}$ of L-NNA aggravates ethanol induced mucosal damage, the attenuation by L-NNA of the protective effect of hydrotalcit was investigated by comparison with controls injected intravenously with L-NNA $(40 \mathrm{mg} / \mathrm{kg}$ ) and treated orally with $M C$ or acidified MC.

Further experiments similar to those described above were performed with L-NAME ( $40 \mathrm{mg} / \mathrm{kg}$, orally) 30 minutes before oral dosing of unmodified $(750 \mathrm{mg} / \mathrm{kg}$ ) or acidified (200 $\mathrm{mg} / \mathrm{kg}$ ) hydrotalcit. In additional sets of experiments, the effects of intravenous injection $(50 \mathrm{mg} / \mathrm{kg})$ of L-NNA on the protective effect of acidified hydrotalcit and the effect of graded doses $(10-50 \mathrm{mg} / \mathrm{kg}$, intravenously) of L-NNA on the protection conferred by unmodified hydrotalcit were studied. Finally, the specificity of the L-NNA (40 mg/kg, intravenously) effect was investigated using intravenous injections of L-arginine or D-arginine $(400 \mathrm{mg} / \mathrm{kg}$ each, dissolved in $2.5 \mathrm{ml} / \mathrm{kg}$ of saline) before administration of unmodified hydrotalcit $(750 \mathrm{mg} / \mathrm{kg})$.

\section{Functional ablation of afferent neurons}

Rats were treated with a subcutaneous injection of capsaicin $(25$ and $50 \mathrm{mg} / \mathrm{kg}$ on day $1,50 \mathrm{mg} / \mathrm{kg}$ on day 2). Capsaicin was dissolved in $10 \%$ ethanol, $10 \%$ Tween 80 , and $80 \%$ saline ( $\mathrm{vol} / \mathrm{vol} /$ vol). Control animals received equal volumes $(0.5 \mathrm{ml})$ of vehicle. All injections were given under ether anaesthesia. Rats were used for experiments 14 days after this treatment. On the day before the experiments, the effectiveness of the treatment was ascertained by evaluating the reduction in the protective wiping movements in response to intraocular instillation of a $0.1 \mathrm{mg} / \mathrm{ml}$ solution of capsaicin as described previously. ${ }^{18}$ Furthermore, in some rats in each experimental group, the loss of protection against ethanol induced gastric damage in response to oral capsaicin $(0.5 \mathrm{mg} / \mathrm{kg})$ was assessed.

Indomethacin induced gastric lesions

Rats were treated orally with graded doses of unmodified $(80-750 \mathrm{mg} / \mathrm{kg}$ ) or acidified (80$320 \mathrm{mg} / \mathrm{kg}$ ) hydrotalcit 60 minutes before administration of indomethacin $(20 \mathrm{mg} / \mathrm{kg}$, orally). Five hours after dosing of indomethacin, the stomach was removed and mucosal damage was assessed. Then mucosal fragments were excised and incubated for determination of prostaglandin formation. In an additional set of experiments, gastric mucosal damage in rats pretreated $(60$ minutes $)$ with unmodified $(750 \mathrm{mg} / \mathrm{kg})$ or acidified $(200 \mathrm{mg} / \mathrm{kg})$ hydrotalcit was assessed 16 hours after administration of indomethacin $(20 \mathrm{mg} / \mathrm{kg}$, orally).

To investigate whether a functioning prostaglandin system is a prerequisite for the protective effect of hydrotalcit, studies were performed in 
which unmodified hydrotalcit $(750 \mathrm{mg} / \mathrm{kg})$ was administered orally 30,60 or 120 minutes after dosing of the ulcerogen indomethacin (20 $\mathrm{mg} / \mathrm{kg}$ orally). Rats were sacrificed 5 hours after indomethacin administration and mucosal damage and prostaglandin formation were assessed.

\section{GASTRIC EICOSANOID MEASUREMENTS}

Formation of eicosanoids by mucsoal tissue ex vivo In groups of rats treated with unmodified $(80-750 \mathrm{mg} / \mathrm{kg})$ or acidified $(200 \mathrm{mg} / \mathrm{kg})$ hydrotalcit and challenged with intragastric instillation of ethanol $(1.5 \mathrm{ml})$ mucosal fragments were excised from areas between the necrotic bands, blotted, and weighed and tissue aliquots of $40 \mathrm{mg}$ were incubated in oxygenated Tyrode solution at $37^{\circ} \mathrm{C}$ for 10 minutes. Release of $\mathrm{PGE}_{2}$, 6-keto$\mathrm{PGF}_{1 \alpha}$, and $\mathrm{LTC}_{4}$ into the incubation medium was measured using specific radioimmunoassays as described in detail previously. ${ }^{17}$ In further experiments, gastric mucosal eicosanoid formation was determined 60 minutes after oral administration of unmodified $(750 \mathrm{mg} / \mathrm{kg})$ or acidified $(200 \mathrm{mg} / \mathrm{kg})$ hydrotalcit without ethanol challenge.

Release of eicosanoids into the gastric lumen in vivo Rats were treated orally with unmodified hydrotalcit $(750 \mathrm{mg} / \mathrm{kg})$. One hour later the animals were anaesthetised with urethane and the abdomen was opened by a midline incision.

Figure 1: Effect of hydrotalcit on ethanol or indomethacin induced gastric lesions. Rats were treated orally with unmodified (um) or acidified (acid) hydrotalcit 60 minutes before oral administration of ethanol $(1.5 \mathrm{ml})$ or indomethacin $(20 \mathrm{mg} / \mathrm{kg})$. Acidified MC had no protective effect. Results are expressed as percentage inhibition of damage produced by ethanol (lesion index $47(4), n=12$ ) or indomethacin (lesion index $21(3), n=12$ ) in vehicle treated control rats. Each point represents the mean (SEM) of 6 experiments.

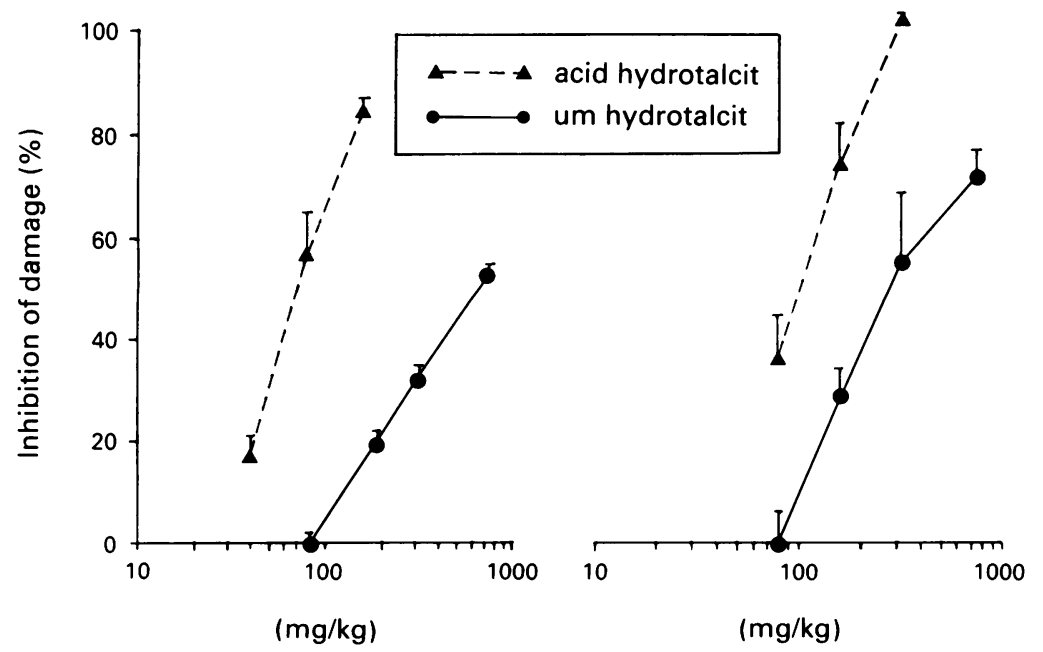

authentic standard prostaglandins that were extracted identical to gastric juice samples. To exclude the possibility that hydrotalcit present in the gastric lumen interferes with measurements of the prostaglandins, various amounts of exogenous 6-keto-PGF $1 \alpha$ and $\mathrm{PGE}_{2}$, respectively, were added to aliquots of gastric contents obtained from rats 60 minutes after oral treatment with unmodified hydrotalcit $(750 \mathrm{mg} / \mathrm{kg}$ ) or MC $(0.25 \%)$. These samples were extracted and analysed by radioimmunoassays as described above.

\section{INDOMETHACIN BIOAVAILABILITY STUDIES}

To investigate whether administration of hydrotalcit interferes with the absorption of indomethacin, concentrations of indomethacin in serum and inflammatory exudates as well as effects of indomethacin on accumulation of eicosanoids and leukocytes in inflammatory exudates were assessed.

\section{SERUM INDOMETHACIN CONCENTRATIONS}

Groups of rats were treated orally with unmodified hydrotalcit $(750 \mathrm{mg} / \mathrm{kg}$ ) or vehicle 60 minutes before administration of indomethacin $(20 \mathrm{mg} / \mathrm{kg}$, orally). Blood samples $(0 \cdot 2 \mathrm{ml})$ were obtained by cardiac puncture $0 \cdot 5,1,2,3,4$, and 5 hours after dosing of indomethacin. In additional experiments, blood samples were obtained 5 hours after administration of indomethacin $(20 \mathrm{mg} / \mathrm{kg}$, orally) in rats pretreated with acidified hydrotalcit $(160 \mathrm{mg} / \mathrm{kg}, 60$ minutes). Blood samples were centrifuged and indomethacin concentrations were measured in aliquots $(10 \mu \mathrm{l})$ of serum using a radioimmunoassay developed in our laboratory. Antiindomethacin antibodies have been raised in a rabbit immunised with an indomethacin-bovine serum albumin-conjugate synthesised using the carbodi-imide method. The antiserum could be used for a sensitive radioimmunoassay (detection limit $58 \mathrm{pg}, 50 \%$ replacement of $\left[{ }^{[+} \mathrm{C}\right]$-indomethacin by 505 pg indomethacin). The indomethacin metabolite O-desmethylindomethacin showed a relative cross reaction of $33 \%$, N-deschlorobenzoylindomethacin did not interfere in amounts up to $50 \mathrm{ng}$. Previous studies in rats have shown the virtual absence in plasma of significant quantities of these metabolites. ${ }^{19}$ The material measured by the radioimmunoassay represents, therefore, unmetabolised indomethacin. Serum concentrations of indomethacin were calculated using dilution curves of authentic indomethacin generated in the same volume $(10 \mu \mathrm{l})$ of serum obtained from rats not treated with indomethacin.

\section{Inflammatory exudates}

Rats were treated orally with unmodified hydrotalcit $(750 \mathrm{mg} / \mathrm{kg})$ or vehicle $(\mathrm{MC}, 2.5$ $\mathrm{ml} / \mathrm{kg}$ ) 60 minutes before subcutaneous implantation of sterile polyester sponges soaked in $2 \%$ carrageenin. Immediately after sponge implantation, indomethacin $(20 \mathrm{mg} / \mathrm{kg})$ was administered orally. The sponges were removed 
Figure 2: Time course of the protective effect of hydrotalcit. Rats were treated orally with unmodified (um) or acidified (acid) hydrotalcit and were challenged with intragastric instillation of ethanol $(1 \cdot 5$ ml) 1-16 hours later. Five minutes after ethanol instillation gastric mucosal damage was assessed. Lesion index in vehicle treated control rats was 45 (3). Results are shown as the percentage inhibition of damage and represent the mean (SEM) of 4-12 rats in each group.

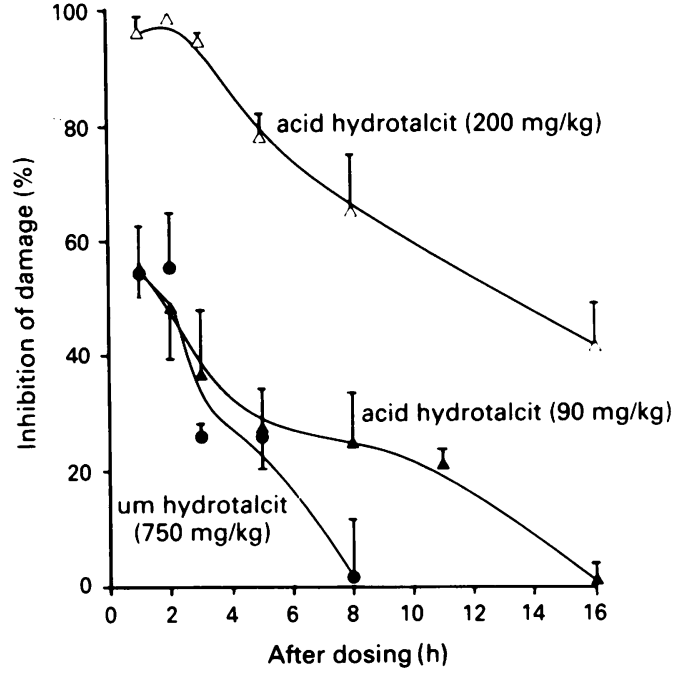

5 hours after implantation and immersed in $2 \mathrm{ml}$ of phosphate buffered saline containing heparin $(5 \mathrm{U} / \mathrm{ml})$. They were then squeezed and the exudates were centrifuged at $1500 \mathrm{~g}$ at $4^{\circ} \mathrm{C}$ for 10 minutes. $\mathrm{PGE}_{2}$ and sulphidopeptide leukotrienes in the supernatants were determined radioimmunologically. The occurrence of $\mathrm{PGE}_{2}$ (data not shown) and sulphidopeptide leukotrienes (mixture of $\mathrm{LTC}_{4}, \mathrm{LTE}_{4}$, and $\mathrm{LTD}_{4}$,) in inflammatory exudates has previously been confirmed using high performance liquid chromatography..$^{20}$ The sediments of the exudates were resuspended in $1 \mathrm{ml}$ of heparinised phosphate buffered saline and leukocyte counts were determined using a Neubauer counting chamber and Türk's solution for cell staining. The methods used have been described in detail previously. ${ }^{20}$ damage was assessed 5 minutes later. In further sets of experiments, rats pretreated with capsaicin to cause functional ablation of afferent neurons received oral unmodified $(750 \mathrm{mg} / \mathrm{kg})$ or acidified $(200 \mathrm{mg} / \mathrm{kg}$ ) hydrotalcit 60 minutes before ethanol challenge. Each bar represents the mean (SEM) of six experiments. $\star_{p}<0.05,{ }^{\star \star} p<0.001 \mathrm{v}$ controls; $+p<0.01 \mathrm{v}$ rats treated with unmodified hydrotalcit only.

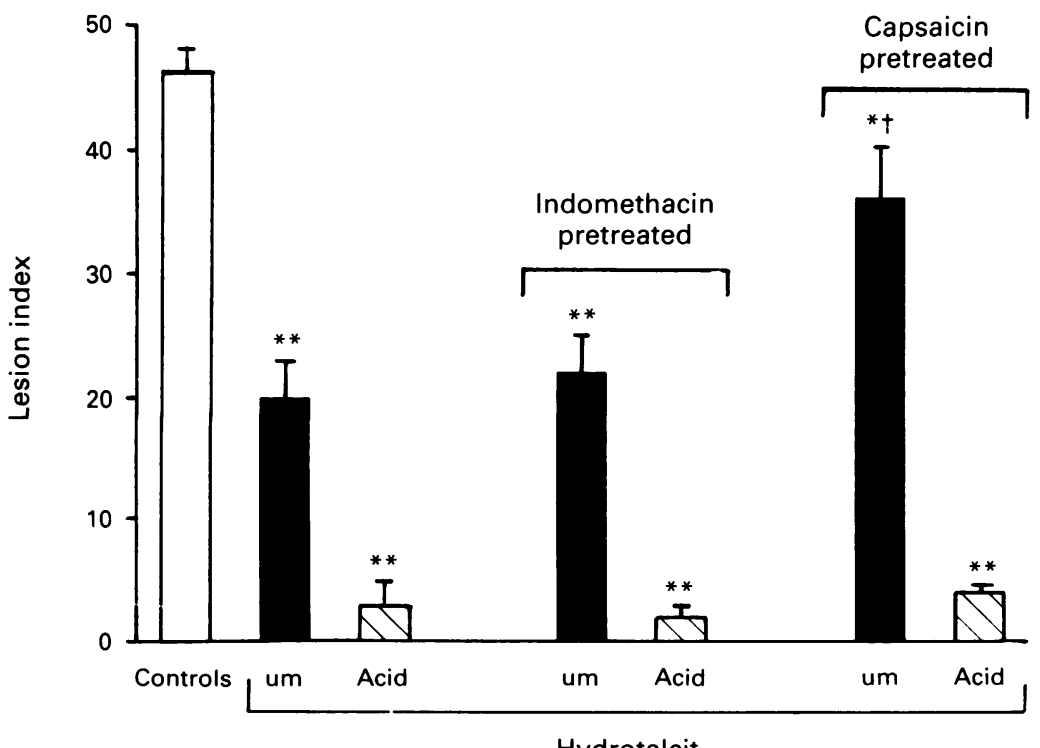

analysis of covariance. A value of $\mathrm{p}<0.05$ was considered significant.

\section{Results}

PROTECTIVE EFFECT OF HYDROTALCIT AGAINST ETHANOL INDUCED LESIONS

Both unmodified and acidified hydrotalcit induced dose dependent protection against gastric mucosal damage caused by ethanol. As shown in Figure 1, acidification of hydrotalcit considerably enhanced the protective effect. While the maximum dose of unmodified hydrotalcit $(750 \mathrm{mg} / \mathrm{kg})$ which can be introduced into the stomach only partially prevented ethanol induced gastric mucosal damage, complete protection could be achieved with acidified hydrotalcit (Figs 1 and 2). Furthermore, protection by acidified hydrotalcit lasted considerably longer than that of unmodified hydrotalcit. Thus, acidified hydrotalcit $(200 \mathrm{mg} / \mathrm{kg})$ reduced ethanol induced damage 16 hours after drug administration by $47 \%$ (lesion index 24 (4), $n=8 v 45$ (3), $n=6$, in vehicle treated control rats, $\mathrm{p}<0.002$ ). In contrast, the protective effect of unmodified hydrotalcit was lost 8 hours after dosing. The decline of protection over time as determined by the slopes of the curves shown in Figure 2 was significantly $(\mathrm{p}<0.05)$ different between acidified $(90 \mathrm{mg} / \mathrm{kg})$ and unmodified $(750 \mathrm{mg} / \mathrm{kg})$ hydrotalcit despite identical initial protection.

\section{Effects of indomethacin and functional ablation of afferent neurons}

Pretreatment with indomethacin $(20 \mathrm{mg} / \mathrm{kg}$, subcutaneously) significantly $(\mathrm{p}<0.001, \mathrm{n}=6$ in each group) reduced gastric mucosal formation of 6-keto-PGF $F_{1 \alpha}$ in rats treated with unmodified hydrotalcit $(750 \mathrm{mg} / \mathrm{kg})$ and challenged with ethanol from 691 (54) to 28 (17) and of $\mathrm{PGE}_{2}$ from 689 (72) to 33 (14). In rats treated with acidified hydrotalcit $(200 \mathrm{mg} / \mathrm{kg})$ before ethanol indomethacin pretreatment reduced $(\mathrm{p}<0.001$, $\mathrm{n}=6$ in each group) mucosal formation of 6-keto$\mathrm{PGF}_{1 \alpha}$ from 804 (112) to 40 (25) and of $\mathrm{PGE}_{2}$ from $732(66)$ to 31 (19). Despite the appreciable inhibition of prostaglandin formation, subcutaneous administration of indomethacin $(20 \mathrm{mg} / \mathrm{kg}$ ) did not produce gastric mucosal lesions within the observation period of 2 hours. Furthermore, this treatment did not attenuate the protective effect of unmodified or acidified hydrotalcit (Fig 3). Functional ablation of afferent neurons by pretreatment with capsaicin partially counteracted the protective effect of unmodified $(750 \mathrm{mg} / \mathrm{kg})$ but did not affect that of acidified hydrotalcit ( $200 \mathrm{mg} / \mathrm{kg}$ ) (Fig 3).

\section{Effect of inhibitors of NO biosynthesis}

Pretreatment with the NO biosynthesis inhibitor L-NNA $(40 \mathrm{mg} / \mathrm{kg}$ ) partially antagonised the protective effect of unmodified hydrotalcit as indicated by a shift to the right of the dose response curve for protection (Figure 4 ). The effect was significant $(p<0.05)$ with the $500 \mathrm{mg} /$ $\mathrm{kg}$ and $750 \mathrm{mg} / \mathrm{kg}$ dose of hydrotalcit. In contrast, 


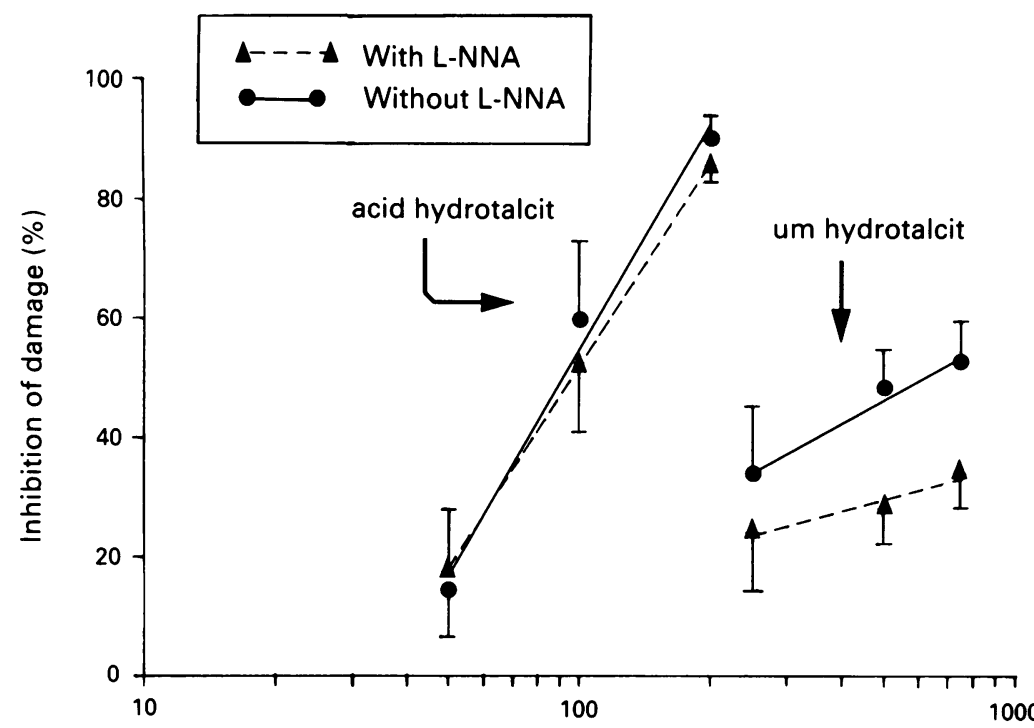

Hydrotalcit $(\mathrm{mg} / \mathrm{kg})$

Figure 4: Effect of L-NNA on hydrotalcit induced protection. Rats were injected intravenously with $L-N N A(40 \mathrm{mg} / \mathrm{kg})$ or saline $(2.5 \mathrm{ml} / \mathrm{kg}) 10$ minutes before oral treatment with graded doses of unmodified (um) or acidified (acid) hydrotalcit and were challenged with ethanol ( $I \cdot 5$ ml) 30 minutes later. All experiments included corresponding control rats treated with $L-N N A$ or saline and methyl cellulose $(M C)$ or acidified MC (5 ml/kg each) instead of hydrotalcit. Each point represents the mean $(S E M)$ of six experiments.

Figure 5: Attenuation of the protective effect of unmodified hydrotalcit by pretreatment with intravenous $L-N N A$ ( 10 minutes) and the effect of $L$-arginine and D-arginine $(400 \mathrm{mg} / \mathrm{kg}$ each, intravenously). Each bar represents the mean (SEM) of six experiments. ${ }^{\star} p<0.05,{ }^{\star \star} p<0.001 \mathrm{v}$ control rats treated with methyl cellulose $(M C)$ (orally) and injected with saline $(2.5 \mathrm{ml} / \mathrm{kg}$, intravenously); $f p<0.02 \mathrm{v}$ rats treated with hydrotalcit only. Each bar represents the mean (SEM) of six experiments.

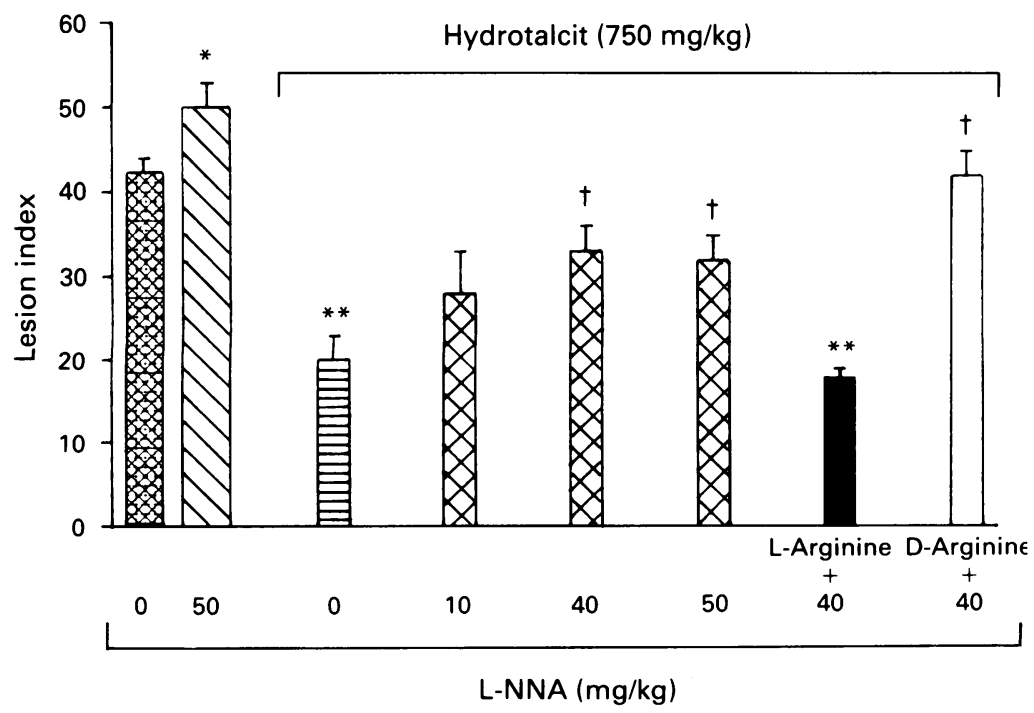

inhibitory effect of L-NNA, while the inactive enantiomere D-arginine was without effect (Fig 5). Identical results were obtained using L-NAME to inhibit endogenous NO production. Thus, L-NAME (40 $\mathrm{mg} / \mathrm{kg})$ significantly attenuated protection by unmodified hydrotalcit $(750 \mathrm{mg} / \mathrm{kg})$ by increasing the lesion index from $17(2)(n=6)$ in rats treated with hydrotalcit only to 31 (3) $(n=6, p<0.01)$ in rats pretreated with L-NAME. In contrast, the protective effect of acidified hydrotalcit was not affected by L-NAME (lesion index $2(0.6) v 4$ (1) in rats treated with acidified hydrotalcit $(200 \mathrm{mg} / \mathrm{kg})$ only, $\mathrm{n}=6$ per group).

\section{EFFECT OF HYDROTALCIT ON GASTRIC EICOSANOID} FORMATION

In rats treated with unmodified $(750 \mathrm{mg} / \mathrm{kg})$ or acidified $(200 \mathrm{mg} / \mathrm{kg})$ hydrotalcit, but not challenged with ethanol, mucosal generation of 6-keto-PGF ${ }_{1 \alpha}$ and $\mathrm{PGE}_{2}$ was not different from that in vehicle treated controls. Furthermore, in ethanol challenged rats, none of the doses of unmodified $(80-750 \mathrm{mg} / \mathrm{kg})$ or acidified $(200$ $\mathrm{mg} / \mathrm{kg}$ ) hydrotalcit studied increased ex vivo gastric mucosal formation of 6-keto-PGF $\mathrm{P}_{1 a}$ or $\mathrm{PGE}_{2}$, and even reduced formation of $\mathrm{PGE}_{2}$ after ethanol exposure, although the effect reached statistical significance for unmodified hydrotalcit $\left(750 \mathrm{mg} / \mathrm{kg}\right.$ ) only. Mucosal generation of $\mathrm{LTC}_{4}$ was significantly increased after ethanol exposure confirming previous results, ${ }^{17}$ and this effect was not attenuated by pretreatment with protective doses of unmodified or acidified hydrotalcit. Results for the maximally effective doses of hydrotalcit are shown in the Table.

Previous studies had shown that measurements of prostaglandins in gastric juice using direct radioimmunoassay do not provide reproducible results. However, using extraction into organic solvents before radioimmunoassay, graded amounts of 6-keto-PGF $1 \alpha$ and $\mathrm{PGE}_{2}$ added to samples of rat gastric contents could be recovered quantitatively and the levels of endogenous prostaglandins fell on the regression lines calculated. Furthermore, thin layer chromatography analysis had shown that immunoreactive material extracted from rat gastric contents cochromatographs exclusively with the corresponding authentic standard prostaglandins. In additional sets of experiments, it was shown that oral administration of unmodified hydrotalcit does not affect measurements of prostaglandins in gastric contents in that it neither binds prostaglandins released into the gastric lumen nor unspecifically interferes with the analytical procedure. Using this method, it was found that treatment with unmodified hydrotalcit in a dose inducing significant protection does not increase the release of 6-keto-PGF ${ }_{1,}$ and $\mathrm{PGE}_{2}$ into the gastric lumen in vivo (Table). Since $\mathrm{LTC}_{4}$ is not stable in the presence of acid, the effects of hydrotalcit on leukotriene release into the gastric lumen were not assessed.

\section{INDOMETHACIN INDUCED GASTRIC LESIONS}

Hydrotalcit dose dependently protected against indomethacin induced gastric lesions, with 
Effect of hydrotalcit on gastric mucosal formation and intraluminal release of eicosanoids in rats challenged or not challenged with ethanol

\begin{tabular}{|c|c|c|c|c|c|c|c|c|}
\hline & \multicolumn{6}{|c|}{ Mucosal fragments } & \multirow{2}{*}{\multicolumn{2}{|c|}{$\frac{\text { Gastric contents }}{\text { Not challenged }}$}} \\
\hline & \multicolumn{3}{|c|}{ Not challenged } & \multicolumn{3}{|l|}{ Challenged } & & \\
\hline & $\begin{array}{l}\text { Controls } \\
(n=10)\end{array}$ & $\begin{array}{l}u m H t \\
(n=6)\end{array}$ & $\begin{array}{l}\text { acid Ht } \\
(n=6)\end{array}$ & $\begin{array}{l}\text { Controls } \\
(n=10)\end{array}$ & $\begin{array}{l}u m \mathrm{Ht} \\
(n=6)\end{array}$ & $\begin{array}{l}\operatorname{acid} H t \\
(n=6)\end{array}$ & $\begin{array}{l}\text { Controls } \\
(n=6)\end{array}$ & $\begin{array}{l}u m H t \\
(n=6)\end{array}$ \\
\hline $\begin{array}{l}\text { 6-keto-PGF }{ }_{1, t} \\
\text { PGE }_{2} \\
\text { LTC }_{+}\end{array}$ & $\begin{array}{c}1048(39) \\
758(92) \\
32(8)\end{array}$ & $\begin{array}{c}998(96) \\
731(58) \\
29(7)\end{array}$ & $\begin{array}{c}1204(87) \\
815(75) \\
33(4)\end{array}$ & $\begin{array}{l}932(161) \\
912(51) \\
310(30)^{\star \star}\end{array}$ & $\begin{array}{l}594(90) \\
577(30) \dagger \\
242(46)^{\star}\end{array}$ & $\begin{array}{l}689(82) \\
712(91) \\
228(51)^{\star}\end{array}$ & $\begin{array}{l}1 \cdot 1(0 \cdot 4) \\
0 \cdot 6(0 \cdot 2) \\
\mathrm{ND}\end{array}$ & $\begin{array}{l}1 \cdot 2(0 \cdot 3) \\
0 \cdot 5(0 \cdot 1) \\
\text { ND }\end{array}$ \\
\hline
\end{tabular}

Rats were treated orally with unmodified (um Ht, $750 \mathrm{mg} / \mathrm{kg}$ ) or acidified (acid Ht, $200 \mathrm{mg} / \mathrm{kg}$ ) hydrotalcit. Controls received $\mathrm{MC}$ $(5 \mathrm{ml} / \mathrm{kg})$. Sixty minutes later the stomach was removed, mucosal fragments were excised, and incubated in Tyrode solution at $37^{\circ} \mathrm{C}$ Additional groups of rats were challenged with ethanol ( $1.5 \mathrm{ml}$, orally) 5 minutes before sacrifice. In further experiments, gastric contents were aspirated 60 minutes after oral dosing of unmodified hydrotalcit or $M C$, extracted and analysed for their content of prostaglandins. Results, shown as ng/g/l0 minutes (mucosal fragments) or ng per stomach (gastric contents) represent the mean ( $\mathrm{SEM}$ ) of ( $\mathrm{n}$ ) experiments in each group. ${ }^{\star} \mathrm{p}<0.01,{ }^{\star} \mathrm{p}<0.001 v$ corresponding rats not challenged with ethanol; $\nmid \mathrm{p}<0.001 v \mathrm{MC}$-treated controls; $\mathrm{ND}=\mathrm{not}$ determined.

Figure 6: Attenuation of indomethacin induced gastric mucosal lesions by hydrotalcit administered after the ulcerogen. Rats were treated with unmodified hydrotalcit $(750 \mathrm{mg} / \mathrm{kg}$, orally) $0 \cdot 5,1$, or 2 hours after dosing of indomethacin (20 mg/kg, orally). Five hours after indomethacin administration gastric damage was assessed and mucosal fragments were incubated to determine formation of 6-keto- $P G F_{\text {Iu }}$ and $P G E_{2}$. Each bar represents the mean (SEM) of six experiments. $\star p<0.001$ v control rats treated with vehicle only; $t p<0.05,+t p<0.001 \mathrm{v}$ rats treated with indomethacin but receiving methyl cellulose instead of hydrotalcit.

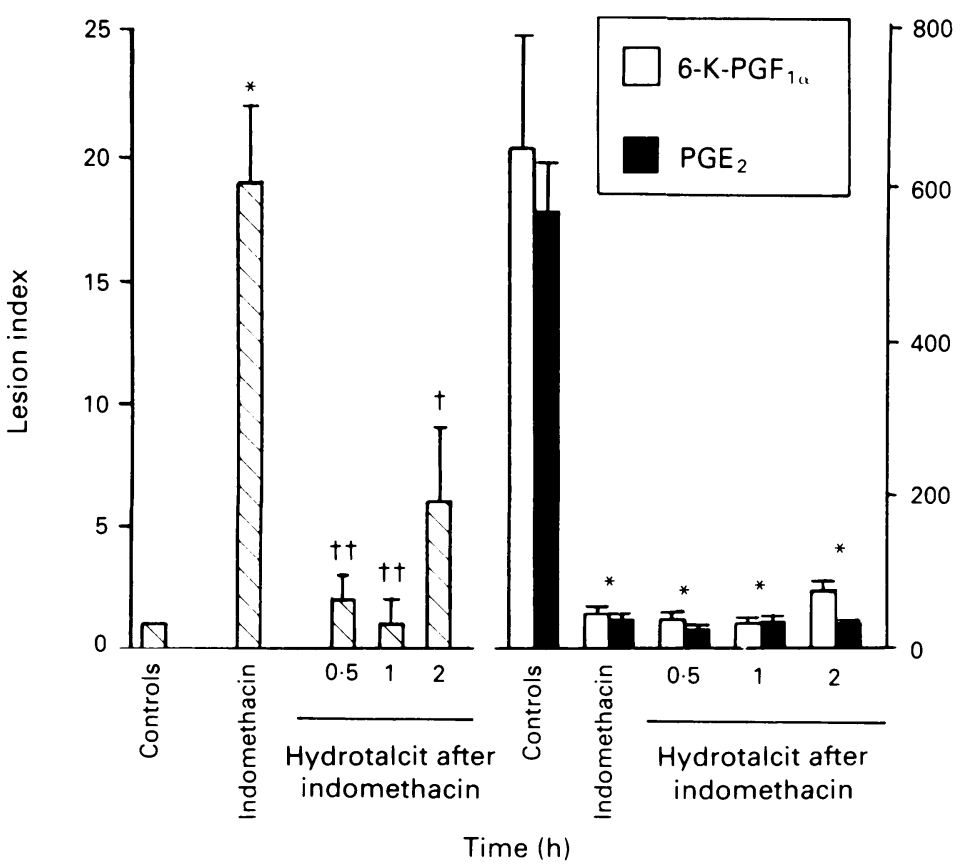

Time (h)

acidification markedly enhancing the effect (Fig 1). Coadministration of hydrotalcit did not attenuate the inhibitory action of indomethacin on the gastric mucosal formation of 6-keto$\mathrm{PGF}_{1 \iota}$ and $\mathrm{PGE}_{2}$ (Fig 6). Protection by hydrotalcit was also observed when the drug was administered up to 2 hours after dosing of indomethacin (Fig 6). Oral administration of indomethacin $(20 \mathrm{mg} / \mathrm{kg})$ alone produced minor gastric mucosal damage (lesion index $5(3), n=4$ ) within 2 hours. This may explain the slightly higher lesion index in rats receiving hydrotalcit 2 hours after indomethacin. Protection by hydrotalcit occurred despite full suppression of the endogenous prostaglandin system. Thus, after treatment with a single dose of indomethacin $(20 \mathrm{mg} / \mathrm{kg}$, orally) near maximal $(\mathrm{p}<0.001 v$ controls) inhibition of mucosal prostaglandin formation ( $\mathrm{ng} / \mathrm{g} / 10$ minutes, $\mathrm{n}=6$ in each group) is reached within 15 minutes (6-keto- PGF $_{10}: 45$ (18); $\mathrm{PGE}_{2}: 43$ (22) and is maintained for 9 hours (6-keto-PGF 1 : $: 37(20)$ PGE $_{2}: 32$ (19)) compared with controls (6-keto-PGF 1 : 852 (69); $\mathrm{PGE}_{2}$ : $799(29))$.

To exclude the possibility that hydrotalcit delays rather than prevents indomethacin induced gastric mucosal damage, injury was assessed 16 hours after administration of the ulcerogen. After this period, the lesion index ( $n=4$ in each group) was 21 (2) in indomethacin $(20 \mathrm{mg} / \mathrm{kg}$, orally) treated rats, $7(2)(\mathrm{p}<0.01)$ in rats pretreated with unmodified hydrotalcit $(750$ $\mathrm{mg} / \mathrm{kg})$, and $3(2)(\mathrm{p}<0.001)$ in rats pretreated with acidified hydrotalcit $(200 \mathrm{mg} / \mathrm{kg})$.

Treatment with hydrotalcit did not affect the absorption of indomethacin. As shown in Figure 7 , serum concentrations of indomethacin were virtually identical in rats pretreated with unmodified hydrotalcit $(750 \mathrm{mg} / \mathrm{kg})$ or vehicle over the whole study period. Likewise, indomethacin serum concentrations in rats pretreated with a dose of acidified hydrotalcit causing substantial inhibition of indomethacin induced lesions were not different from those in rats treated with indomethacin only (Fig 7).

Figure 8 shows that treatment with hydrotalcit does not affect the anti-inflammatory action of

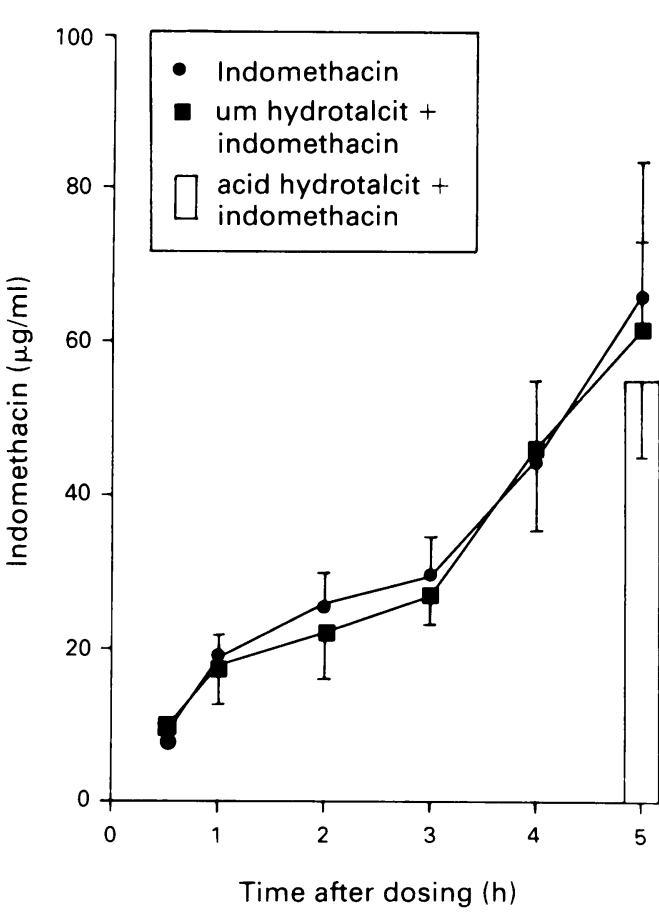

Figure 7: Effect of hydrotalcit on serum concentrations of indomethacin. Rats were treated orally with hydrotalcit or vehicle 60 minutes before administration of indomethacin $(20$ $\mathrm{mg} / \mathrm{kg}$, orally). Indomethacin concentrations in serum were determined $0 \cdot 5-5$ hours after dosing of indomethacin in rats pretreated with methyl cellulose or unmodified (um, $750 \mathrm{mg} /$ kg) hydrotalcit as well as after 5 hours in rats pretreated with acidified (acid, $160 \mathrm{mg} / \mathrm{kg}$ ) hydrotalcit. Each point represents the mean (SEM) of five rats. The bar represents the mean (SEM) of 10 rats pretreated with acidified hydrotalcit. 


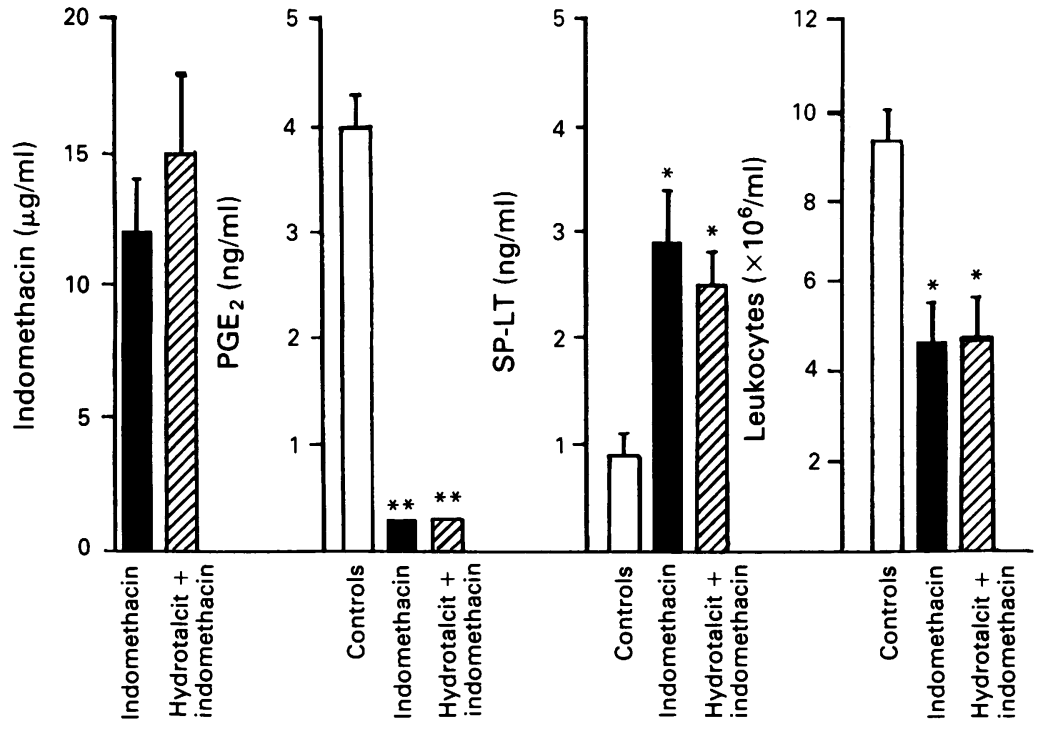

Figure 8: Effect of

hydrotalcit on concentration of indomethacin, $P G E_{2}$, sulphidopeptide leukotrienes $(S P-L T)$, and leukocytes in inflammatory exudates in indomethacin treated rats. Unmodified hydrotalcit or vehicle was administered orally 60 minutes before implantation of carrageenin soaked sponges followed by oral administration of indomethacin $(20 \mathrm{mg} / \mathrm{kg})$.

Five hours after

implantation, concentration of indomethacin, $P G E_{2}$ and sulphidopeptide leukotrienes were measured in the supernatant and leukocytes were counted in the sediment of centrifuged exudates. Bars represent the mean (SEM) of six rats. ${ }^{\star} p<0 \cdot 01$, ${ }_{\star \star} p<0.001 \mathrm{v}$ control rats treated with vehicle only. indomethacin. Thus, release of $\mathrm{PGE}_{2}$ into inflammatory exudates elicited by subcutaneous implantation of carrageenin soaked sponges was reduced to the same extent in rats treated with indomethacin only and rats treated additionally with a protective dose of hydrotalcit. Indomethacin treatment increased the release of sulphidopeptide leukotrienes into inflammatory exudates. This effect was not modified by coadministration of hydrotalcit. Furthermore, the inhibition of influx of leukocytes into inflammatory exudates observed after treatment with indomethacin was not attenuated by hydrotalcit. Finally, concentrations of indomethacin measured in inflammatory exudates were not affected by pretreatment with hydrotalcit.

\section{Discussion}

Hydrotalcit protected against gastric mucosal damage caused by ethanol or indomethacin in a dose dependent manner as shown previously for other aluminum containing antacids. Acidification noticeably enhanced the protective effect. Furthermore, the duration of protection was considerably longer with acidified than with unmodified hydrotalcit. With maximally effective doses, acidified hydrotalcit significantly reduced ethanol-induced gastric mucosal damage even 16 hours after dosing, while the protection conferred by unmodified hydrotalcit was lost after 8 hours. Studies using unmodified and acidified hydrotalcit in doses causing identical initial protection revealed a significant difference in the decline of protection with time suggesting that in addition to the more pronounced initial protective potency different mechanism(s) of action contribute to the prolonged protection by acidified hydrotalcit.

Increased protective efficacy and prolonged duration of action after acidification have been reported previously for various aluminum containing antacids. ${ }^{3-59}$ This effect has been explained by formation of an activated aluminum complex associated with an increased appearance of hexa-aquo-aluminum cation $\left[\mathrm{Al}\left(\mathrm{H}_{2} \mathrm{O}\right)_{6}{ }^{3+}\right] .{ }^{59}$ The precise mechanism underlying the protective effect of unmodified and acidified hydrotalcit, however, is unknown. As acidification of antacids results in loss of acid neutralising capacity, ${ }^{9}$ elevation of intragastric $\mathrm{pH}$ cannot explain the protection. This is supported by the fact that unmodified and acidified hydrotalcit prevent ethanol induced gastric lesions, ${ }^{1-35} 5^{7-9}$ an experimental model known to be independent of intraluminal acid.

The contribution of endogenous prostaglandins to the mucosal protective effects of antacids is controversial. Since the morphological and functional parameters of antacid induced protection are similar to those elicited by prostaglandins, it has been suggested that stimulation of formation of protective prostaglandins in the gastric mucosa by antacids plays a pivotal role in their protective effect. In man and rat, acute or chronic treatment regimens with aluminum containing antacids have been reported to increase prostaglandin formation in gastric mucosal tissue ${ }^{2122}$ and/or to enhance secretion of prostaglandins into the gastric lumen, ${ }^{37102324}$ although not all studies could confirm this effect. ${ }^{325}$ In vitro, aluminum containing antacids released $\mathrm{PGE}_{2}$ from cultured macrophages. ${ }^{26}$ Inhibition of prostaglandin formation was found to fully, ${ }^{110}$ partially, ${ }^{24}$ or not ${ }^{35}$ antagonise antacid induced protection. The findings of this study clearly show that in doses causing substantial protection, both unmodified and acidified hydrotalcit do not increase ex vivo gastric mucosal formation of 6-keto-PGF ${ }_{1 \alpha}$ and $\mathrm{PGE}_{2}$ in rats challenged or not challenged with ethanol. After ethanol exposure, mucosal formation of $\mathrm{PGE}_{2}$ was even decreased in rats treated with unmodified hydrotalcit. Whether this effect is related to tissue preservation as a consequence of protection or results from other, as yet unknown, actions of the compound is not known. Likewise, hydrotalcit did not increase the release of 6keto-PGF ${ }_{1 \alpha}$ and $\mathrm{PGE}_{2}$ into the gastric lumen in vivo. Furthermore, neither preparation of hydrotalcit attenuated the increase in gastric mucosal generation of pro-ulcerogenic $\mathrm{LTC}_{4}$ in response to intraluminal ethanol. Further support that gastroprotective effects of hydrotalcit are independent of the endogenous eicosanoid system comes from the finding that pretreatment with indomethacin in a dose causing near maximal inhibition of gastric mucosal prostaglandin formation did not reduce the protective effect of unmodified or acidified hydrotalcit.

In man, aluminum containing antacids given in therapeutic doses for 4 weeks significantly reduced the rate of gastric microbleeding induced by aspirin. ${ }^{2}$ As the protective effect was short lived only, it was suggested that if reduction of gastrointestinal side effects because of nonsteroidal anti-inflammatory drugs is intended, antacids should be taken regularly 1 hour before the noxious compounds. ${ }^{2}$ In our study, hydrotalcit protected against gastric mucosal lesions caused by indomethacin even when the drug as administered up to 2 hours after the ulcerogen indicating that for therapeutic efficacy predosing of antacids is not necessary. Protection in the presence of full blockade of prostaglandin formation is of major importance for the clinical use of antacids to prevent or treat gastropathy 
induced by non-steroidal anti-inflammatory drugs.

The present results also show that unmodified and acidified hydrotalcit confer protection against indomethacin induced gastric damage and do not only delay the development of lesions, since 16 hours after indomethacin administration significantly less gastric mucosal injury was observed in hydrotalcit pretreated rats.

The effect of antacids on the absorption of non-steroidal anti-inflammatory drugs is not completely understood and depends on the particular compound as well as on the antacid preparation used. ${ }^{27}$ Although in man absorption and disposition of a number of non-steroidal anti-inflammatory drugs was unaffected by combined treatment with antacids (for review $\operatorname{see}^{28}$ ), reduced bioavailability of indomethacin during coadministration of aluminum and magnesium containing antacids has been described. ${ }^{29}$ Most non-steroidal antiinflammatory drugs are weak acids. In an acidic milieu they exist in the unionised form, which is highly lipophilic and easily absorbed into mucosal cells. Increasing the intraluminal $\mathrm{pH}$ value by antacids with buffering capacity could possibly interfere with the local absorption of non-steroidal anti-inflammatory drugs from the stomach and thus reduce their gastric toxicity and anti-inflammatory potency. Our results provide evidence that the protective effect of acid neutralising unmodified hydrotalcit is not associated with less marked inhibition of gastric mucosal prostaglandin formation. Furthermore, concentrations of indomethacin in serum and/or inflammatory exudates were not different in rats pretreated with unmodified or acidified hydrotalcit compared with rats treated with indomethacin only. As shown previously, ${ }^{20}$ treatment with indomethacin substantially inhibited release of $\mathrm{PGE}_{2}$, increased secretion of sulphidopeptide leukotrienes and reduced influx of leukocytes into inflammatory exudates produced after subcutaneous implantation of carrageenin induced sponges. These effects of indomethacin were not attenuated by concurrent antacid administration. Taken together, our findings indicate that the protection induced by hydrotalcit against indomethacin induced mucosal injury is not the result of reduced gastric or systemic absorption of the non-steroidal antiinflammatory compound and is not associated with diminished anti-inflammatory activity.

Antacids have been found to elicit gastric mucosal hyperaemia. ${ }^{7}$ Furthermore, aluminum containing antacids prevent ethanol induced injury to endothelial cells suggesting the microvasculature as a possible target of their protective effect. Recently, NO, which is formed from the amino acid L-arginine by various cells including endothelial cells has been described as potent vasodilator." The biosynthesis of NO is selectively inhibited by analogues of L-arginine such as $\mathrm{N}^{(}$-monomethyl-L-arginine (L-NMMA), L-NNA, or L-NAME." In rats, inhibition of endogenous $\mathrm{NO}$ formation induced a fall in resting gastric mucosal blood flow. ${ }^{13}$ While administration of L-NMMA did not induce acute mucosal injury in the rat stomach, capsaicin pretreatment causing functional ablation of afferent neurons and/or concurrent treatment with indomethacin induced severe haemorrhagic necrotic damage suggesting that $\mathrm{NO}$ acts in concert with sensory neuropeptides and prostaglandins in the modulation of gastric mucosal integrity. ${ }^{12}$

Pretreatment with L-NNA increased the extent of gastric injury induced by ethanol suggesting that endogenous NO represents a compensatory mechanism partly limiting damage to the mucosa. Inhibition of NO biosynthesis by L-NNA and L-NAME partially antagonised the prevention of ethanol induced gastric lesions by unmodified hydrotalcit. The attenuating effect of L-NNA was reversed by concurrent administration of the substrate of NO-synthase, L-arginine, indicating the specificity of the L-NNA effect. Likewise, functional ablation of afferent neurons induced by pretreatment with a neurotoxic dose of capsaicin partially reduced the protective effect of unmodified hydrotalcit. Intragastric administration of capsaicin protects against mucosal injury caused by various noxious agents including ethanol..$^{30}$ This protection involves stimulation of afferent neurons in the gastric mucosa and is abolished by functional ablation of these neurons induced by a neurotoxic dose of capsaicin. ${ }^{30}$ Gastroprotection induced by intragastric capsaicin is not associated with increased formation of $\mathrm{PGE}_{2}$ or 6-keto-PGF $\mathrm{PG}_{\mathrm{l}}$ and is not attenuated by pretreatment with indomethacin, indicating that it is not prostaglandin mediated..$^{31}$ In contrast, treatment with the inhibitor of NO biosynthesis, L-NNA, fully abolished capsaicin induced protection. ${ }^{1+}$ Aluminum containing antacids have been found to produce distinct morphological changes in normal rat gastric mucosa, including disruption of surface epithelial cells. ${ }^{7}$ Whether such changes are sufficient to elicit stimulation of afferent neurons in the gastric mucosa or whether the increased NO formation is mediated by other, possibly indirect, mechanisms remains to be investigated. Although the dose of L-NNA necessary to completely block capsaicin induced protection $(5 \mathrm{mg} / \mathrm{kg})^{1+}$ is considerably lower than that partially attenuating the protective effect of unmodified hydrotalcit, the parallel attenuation of the protective effect of unmodified hydrotalcit by inhibition of NO formation and functional ablation of afferent neurons is 'of interest and warrants further investigations. We have previously shown that NO is not an essential mediator of the gastroprotection induced by prostaglandins such as 16,16 -dimethyl-PGE 2 , the $\mathrm{PGI}_{2}$ analogue iloprost, and the $\mathrm{PGE}_{2}$ analogue nocloprost. ${ }^{32}$ This is further support of the concept that prostaglandins are not crucially involved in the protective property of unmodified hydrotalcit.

Unlike unmodified hydrotalcit, the protection conferred by acidified hydrotalcit is completely independent of the endogenous NO system and is not attenuated by functional ablation of afferent neurons. The failure of inhibition of $\mathrm{NO}$ formation and capsaicin pretreatment to attenuate the protection by acidified hydrotalcit is not due to the near maximal protection elicited by this hydrotalcit preparation. It was also observed with doses causing only partial prevention of 
ethanol induced gastric damage comparable with the protection conferred by unmodified hydrotalcit. Taken together, the findings of the study indicate that endogenous eicosanoids are not essential mediators of the protective effects of unmodified and acidified hydrotalcit. Protection by hydrotalcit against indomethacin induced gastric lesions is not associated with reduced absorption and diminished antiinflammatory activity of the non-steroidal antiinflammatory drug. The mechanism of protection by unmodified hydrotalcit is partly related to endogenous $\mathrm{NO}$ and afferent neurons and partly independent of these systems. In contrast, endogenous NO and afferent neurons do not contribute to the protection by acidified hydrotalcit suggesting that different mechanisms mediate the mucosal protective effects of acid neutralising and non-buffering antacids.

Results have been presented in part at meetings of the American Gastroenterological Association in 1990 (San Antonio, USA).
(Trautmann M, Peskar BM. Gastroprotection in rats by the (Trautmann M, Peskar BM. Gastroprotection in rats by the antacids hydrotalcit and maalox does not involve the endogenous prostaglandin and leukotriene system. Gastroenterology 1990; 98:
A139) and in 1992 (San Francisco, USA) (Lambrecht N, $\mathrm{A} 139$ ) and in 1992 (San Francisco, USA) (Lambrecht N Korolkiewicz R, Peskar BM. Effects of endogenous nitric oxide
(NO) inhibition of the gastroprotective activity of the antacid hydrotalcit in rats. Gastroenterolog 1992 ; 102: A 105).

1 Szelenyi I. Functional cytoprotection by certain antacids. Acta Physiol Hung 1984; 64: 259-68.

2 Domschke W, Hagel J, Ruppin H, Kaduk B. Antacids and gastric mucosal protection. Scand 7 Gastroenterol 1986; 21 (suppl 125): 144-9.

3 Konturek SJ, Brzozowski T, Drozdowicz D, Nauert Ch. Role of intragastric $\mathrm{pH}$ in cytoprotection by antacids in rats. Eur of intragastric pH in cytoprotection

f Pharmacol $1990 ; 176: 187-95$.
4 Fitzpatrick LR. Protection by acidified maalox against indomethacin-induced gastric antral ulceration in hamsters. indomethacin-induced

5 DiJoseph JH, Borella LE, Wells CL, Nabi Mir G. Mucosal protective activity of activated aluminum complex. Digestion 1990; 45: 19-25.

6 Hagel J, Renner H, Hirsch M, Weig G, Kaduk B, Ruppin H, et al. Gastric cytoprotection by antacids and papaverine in rats. Hepatogastroenterology 1982;29: 271-4.

7 Tarnawski A, Hollander D, Cummings D, Krause WJ Gergely H, Zipser RD. Are antacids acid neutralisers only? Histology, ultrastructural and functional changes in normal gastric mucosa induced by antacids. Gastroenterology 1984 ; 86: 1276

8 Tarnawski A, Hollander D, Gergely H, Stachura J. Com parison of antacid, sucralfate, cimetidine and ranitidine in protection of the gastric mucosa against ethanol injury. $A m \mathcal{F}$ Med 1985; 79: 19-23

9 DiJoseph JF, Borella LE, Nabi Mir G. Activated aluminum complex derived from solubilized antacids exhibits enhance cytoprotective activity in the rat. Gastroenterology 1989; 96: $730-5$.

10 Szelenyi I, Postius S, Engler H. Evidence for a functional cytoprotective effect produced by antacids in the rat stomach. Eur 7 Pharmacol 1983; 88: 403-6.
11 Moncada S, Palmer RMJ, Higgs EA. Nitric oxide: physiology, pathophysiology, and pharmacology. Pharmacol Rev 1991 43: $109-42$.

12 Whittle BJR, Lopez-Belmonte J, Moncada S. Regulation of gastric mucosal integrity by endogenous nitric oxide: interactions with prostanoids and sensory neuropeptides in the rat. Br f Pharmacol 1990; 99: 607-11.

13 Tepperman BL, Whittle BJR. Endogenous nitric oxide and sensory neuropeptides interact in the modulation of the rat
microcirculation. Brf Pharmacol 1992; 105: 171-5.

14 Peskar BM, Respondek M, Müller KM, Peskar BA. A role of nitric oxide in capsaicin-induced gastroprotection. Eur $\mathcal{F}$ Pharmacol 1991; 198: 113-4.

15 Dembinska-Kiec D, Pallapies D, Peskar BM, Peskar BA Effect of carbenoxolone on the biological activity of nitric oxide: relation to gastroprotection. Br f Pharmacol 1991; 104: $811-6$.

16 Prieto R, Martinez-Tobed A, Fábregas JL, Beneyto JE. In vitro comparison of the antacid potencies of almagate in tablets and suspension with those of other commercially tablets and suspension with those of other commercially

available antacid preparations. Drug Res $1984 ; 34: 1360-4$.
17 Peskar BM. Role of leukotriene $C_{4}$ in mucosal damage caused by necrotizing agents and indomethacin. Gastroenterology by necrotizing age.

18 Gamse R, Capsaicin and nociception in the rat and mouse. Naunyn Schmiedebergs Arch Pharmacol 1982; 320: 205-16.

19 Hucker HB, Zacchel AG, Cox SV, Brodie DA, Cantwel NHR. Studies on the absorption, distribution and excretion of indomethacin in various species. I Pharmacol Exp Ther 1966; 153: 237-49.

20 Peskar BM, Trautmann M, Nowak P, Peskar BA. Release of 15-hydroxy-5,8,11,13-eicosatetraenoic acid and cysteinylleukotrienes in carrageenin-induced inflammation: Effect of non-steroidal anti-inflammatory drugs. Agents Actions 1991; 33: $240-6$.

21 Preclik G, Stange EF, Gerber K, Fetzer G, Horn H, Ditschuneit H. Stimulation of mucosal prostaglandin Ditschuneit $\mathrm{H}$. Stimulation of mucosal prostaglandin synthesis in human stomach and
treatment. Gut 1989; 30: 148-51.

22 Gasbarrini G, Andreone P, Baraldini M, Cursaro C, Micaletti E. Antacids in gastric ulcer treatment: evidence of cytoprotection. Scand 7 Gastroenterol 1990; 25 (suppl 174); 44-7.

23 Berstad K, Vergin H, Postius S, Weberg R, Szelenyi I, Berstad A. Gastric prostaglandin $E_{2}$ release induced by aluminium hydroxide and aluminium hydroxide-containing antacids in rats. Effect of low doses and citric acid. Scand 7 Gastroenterol 1987; 22: 884-8.

24 Vergin $\mathrm{H}$, Kori-Lindner C. Putative mechanisms of cytoprotective effect of certain antacids and sucralfate. Dig Dis protective effect of cer

25 Weberg R, Berstad K, Berstad A. Acute effects of antacids on gastric juice components in duodenal ulcer patients. Eur $\mathscr{f}$ Clin Invest 1990; 20: 511-5.

26 Szelenyi I, Lanz R. Release of cytoprotective $\mathrm{PGE}_{2}$ from cultured macrophages induced by antacids and sucralfate. Agents Actions 1986; 18: 375-8

27 Hurwitz A. Antacids therapy and drug kinetics. Clin Pharmacokinet 1977; 2: 269-80.

28 Gugler $\mathrm{R}$, Allgayer $\mathrm{H}$. Effects of antacids on the clinical pharmacokinetics of drugs. An update. Clin Pharmacokinet 1990; 18: 210-9.

29 Galeazzi RL. The effect of an antacid on the bioavailability of indomethacin. Eur f Clin Pharmacol 1977; 12: 65-8.

30 Holzer P, Lippe IT. Stimulation of afferent nerve endings by intragastric capsaicin protects against ethanol-induced damage of gastric mucosa. Neuroscience 1988; 27: 981-7.

31 Holzer P, Pabst MA, Lippe IT, Peskar BM, Peskar BA Livingston EH, Guth PH. Afferent nerve-mediated protection against deep mucosal damage in the rat stomach. Gastroenterology 1990; 98: 838-48.

32 Peskar BM, Pallapies D, Dembinska-Kiec A, Kluge S, Peska BA. Role of nitric oxide in gastroprotection. Digestion 1991 49 (suppl 1): 8-9. 